\title{
Subaltern Perspectives in Jane Eyre and Wide Sargasso Sea: A Comparative Study
}

\section{Sahabuddin Ahamed}

\begin{abstract}
This paper analyses the textual function of cultural representation of subaltern identity in the construction and maintenance of First and Third World relations in Charlotte Bronte's Jane Eyre and Jean Rhys's Wide Sargasso Sea. It focuses on dominant discursive practices that pervade the texts, exploring how the hegemonic ideology of the West is operational in constructing value systems while simultaneously rendering the Third World subjects as subaltern. Both works are upheld by language use that facilitates the understanding of hierarchical structures of power relations and the possibilities of resistance to that project. It shows how Mr. Rochester has been a dominant voice and an authoritative figure in the dehumanizing legacy of patriarchy and imperialism. In Jane Eyre the dominant discursive space restricts the individual identity of Bertha Mason about whom no subjective voice is given to her to claim her identity. But Wide Sargasso Sea functions as a "re-inscription" of Jane Eyre in the sense that Antoinette/Bertha voices and struggle for her identity. Her subjectivity and individual identity are not given but distorted by dominant power structures and discourses that presents ideological contention in the existing social relations and identities.
\end{abstract}

\section{Keywords}

Subaltern, Female Psyche, Colonial Discourse, Postcolonial, Bertha Mason. 


\title{
Subaltern Perspectives in Jane Eyre and Wide Sargasso Sea: A Comparative Study
}

\author{
Sahabuddin Ahamed
}

The ideological function of racism and imperialism was generally associated with the political domination and economic wealth of those racist groups who aimed to impose their cultural value systems upon the non-Europeans. The racial superiority of white people is centered on an act of 'Manichaean allegory' of binary power relations between colonizer and colonized, self and other, modern and primitive, and rational and emotional (Mohamed 63). By imperialist and colonialist discourses Europeans started to exercise all kinds of new ideologies that supported neo-white supremacy everywhere in the world. It became a particular phase of capitalist development in which markets and labors shift to peripheral territories, and this act also led many European countries to compete with each other to exhibit their power and attain more territories abroad. These processes of exploitation, domination, and subordination created an ambiance of conflict between the "use value" of indigenous people and the "exchange value" of the colonizer (60-61). The ideological and discursive practices of imperialism as an act of conservation of Western values in the name of education, civilizing ideals, and progress is grounded in the social, cultural, political, and economic relations of colonialism and patriarchy. There is often a symbolic and allegorical relationship between these material and discursive practices found in all stereotypical cultural artifacts, the commodification of colonized subjects, and disparate modes of production. The colonialist discourse becomes replete with the imperialist one in terms of exploitation of resources, the capture of foreign territories, and subjugation of natives in such a way that the binary relations between the colonizer-subject and the colonized-object are grounded on a "transformation of racial difference into moral and even metaphysical difference" (61).

The dominant Western discourse ignores the voices of women, oppressed subjects, colonized people, non-whites, silenced underneath the deepest racial and gender discrimination. Ania Loomba states that it is the dominant discursive function of the West that both women and non-Europeans are always represented and stereotyped as passive, emotional, primitive, irrational, wild, and lower races. It traces the "connections between the visible and the hidden, the dominant and the marginalized, ideas and institutions. It allows us to see how third-world subject, power works through language, literature, culture, and the institutions which regulate our daily lives" (45). The structure 
of racism, colonialism, imperialism, and patriarchy abandons their voices and confer them the status of "lower-ranking" or marginalized who are doubly colonized by the colonial past and the postcolonial present in their society.

The subaltern cannot speak, not in the sense that she does not attempt to claim her own position and individual identity, but she is always distorted by the "complicit nature" of the Western discourse to interact with disparate cultures, "literature, and the intellectual elite which often appears innocent in the political realm of oppression" (Maggio 420). Gyan Prakash points out that "the actual subalterns and subalternity emerge between the folds of the discourse, in its silences and blindness, and its overdetermined pronouncements" (1482). It is suggested that the "lack of cohesion and organization" and fragmentation of subalterns and their subjection to the initiative of the dominant groups render them "politically impotent," "incapable of giving them a centralized expression to their aspirations and needs," their utmost unification, individual identity, and right claim result in successive failure (Buttigieg 36). This whole process of governing civil society is done through 'institutional and cultural mechanism' of what Louis Althusser calls the 'ideological state apparatus,' i.e. the material organizations and institutions of the state or the governing bodies meant to preserve, defend, and develop the theoretical or ideological front of those controlling systems.

The exclusive Western projections of Eurocentrism, universalism, civilization, self, racial superiority, power relation, truth claim, enlightenment, emancipation, humanitarianism, knowledge production, and subjectivity are devised by the narrator Mr. Rochester in Charlotte Bronte's Jane Eyre and also in the Second Part of Jean Rhys's Wide Sargasso Sea. Both novels are complementary to each other and reveal the colonialist substructure of the early nineteenth-century British society. Through the devices of colonialist discourse and ideologies, as they are manifested in Mr. Rochester's use of language, perception, narrative technique, knowledge production, and moral confusion and even in Jane's. Bronte's representation of Bertha Mason and the West Indies is problematic because the white Creole heroine is given no voice to claim her identity; by large they are rendered as subaltern subjects, threatened by colonial violence and enslavement. There are no occasions in which Bertha speaks and on which Jamaicans are presented as members of peaceful, organized and communicative societies. They are associated with demonic and exotic 'Other' as the skeptical and detrimental representations of West Indies in the language of Rochester. In his book Orientalism, Edward Said writes of the processes of becoming Oriental Other in the "Western projection" and "European expansion" who are stamped with "essentialist" Other and "ethnist typology" $(95,97)$. The representation of Bertha Mason and the West Indies is done in the Orientalist project by Rochester.

Rhys's Wide Sargasso Sea acts both as a prequel of Jane Eyre and a postcolonial response to Jane Eyre by giving the silenced Bertha Mason a voice. The subaltern identity of Bertha Mason/Antoinette Cosway is devised through the narrative strategies and dominant ideologies of colonial structure in Jane Eyre. Is Bertha/Antoinette really mad or forced to behave like madness? What are the true reasons of her madness? Are 
the positions of subaltern people like Bertha Mason really natural or given? What roles do her husband play to drive her mad? If we go through both texts, we find different complications of narrative technique and truth claim, actual happenings, true nature of Bertha Mason, Jane and Rochester, and the 'Manichaean dualism' on which both texts operate; but in Wide Sargasso Sea from a different angle, we find what lacks in Jane Eyre.

\section{The Representation of the Subaltern Identity of Bertha Mason/Antoinette Cosway in Jane Eyre and Wide Sargasso Sea}

In both texts in regard to the subaltern identity of Bertha Mason we find a different perspective. Rhys's Wide Sargasso Sea deconstructs Bronte's novel' imposed assumption about Bertha in which she is merely 'a mad woman in the attic;' no position, identity, humanity, the voice given to her. Rhys's novel exposes Bertha/ Antoinette's response to colonial discourse and patriarchy devised by Rochester, her husband. By this act, Rhys fills in the gaps within Bronte's novel and writes back the theme of colonial assumptions. Rhys's different kind of text recreates the woman naming Antoinette Cosway and explores the reasons for her mysterious madness. Wide Sargasso Sea is a strong criticism of the strategies of Western master discourse and ideology that lower the position of third world women and make them doubly oppressed and marginalized both by traditional patriarchal social order within their own culture and, beyond that by the colonialist and imperialist attitudes that are very masculinist and racist.

In Jane Eyre, it is Mr. Rochester whose masculinist voice attempts to define and redefine Bertha/Antoinette, reconstructing her character and passing judgment on her behavior, while in Wide Sargasso Sea, Rhys uncovers the ways colonial and patriarchal discourses from both cultures create their interpretation and representation of third world subjects. In exposing the cruelty and effects of such kinds of Western assumptions, we find that both novels reveal similar ideas of how women are fettered to the harsh Victorian values concerning women either 'an angel in the house' or 'a mad woman in the attic.' As the novelistic texts display how Jane becomes an angel when she accepts her enslavement to the patriarchal social order and Bertha becomes a madwoman when she goes against those rules of patriarchy and racial and gender discrimination.

Mr. Rochester represents Bertha and Jamaica on his terms. In both novels, Bertha and Antoinette are not the 'crude' definitions given by their husbands. We see how much others attempt to define Antoinette's identity namely Rochester, Daniel Cosway, and other black Caribbeans. Her husband reflects his desire to control meaning, but Antoinette's voice interrupts him in the Second Part. Meaning and definition are continually contested in this part of the narrative. Instead of strong intertextual relations between the two texts, Wide Sargasso Sea reflects Antoinette Cosway's narrative voice in contrast to her husband and its meaning by criticizing its representation.

From 'subaltern' perspectives, it can be said that the impact of long-term hierarchical situations and dominant colonizing attitudes and cultures make third-world individuals subaltern subjects who are peripheral or marginal not only in their own 
colonized culture but, rather, in the imperialistic, colonializing culture to which they have immigrated or been forcibly taken. Such is the case with the heroine of Bronte and Rhys rendering her identity in a derogatory way to rename her Bertha Mason. In Jane Eyre, Bertha is an oppressed and silenced woman and cannot speak or achieve her identity, self-legitimation, self-determination, fortune, equality, and regeneration. In the same novel, Bronte's heroine, Jane Eyre goes through a transformation of subaltern identity in a privileged way as she is an English girl as opposed to a 'Creole' girl like Bertha. Her ambivalence is partly a function of her race and position in Rochester's family. It is grounded on her dependence or independence. Her transformation occurs through her divided selfhood - a subaltern individual tormented by outer forces and internal suppressive desires to revolt against rigid social norms. Her desire for liberty- "I desired liberty" is changed into a "new servitude" of accepting patriarchal norms that restrict her life (Bronte 73). Her feelings for Rochester signal her subjection to patriarchal authority. What Jane finally possesses is a consequence of Bertha's death in the blaze. Jane's journey towards her self-fulfillment, self-mastery, self-legitimation, and agency is the result of the persistent subservience of Bertha Mason. Jane's selffulfillment and happy marriage are achieved at the cost of Bertha's human selfhood and ultimately, her life. In contrast to Jane, Bertha's subaltern identity is produced by "the axiomatics of imperialism" (Spivak "Three Women's" 247) that is apparent in a number of dichotomies posited between British and Jamaican, good and evil, light and darkness, human and animal, reason and madness, legal and illegal and self and Other. Bertha's representation as a colonized Other functions only to legitimate Jane's self-fulfillment in Western discourse. Spivak points out that the project of imperialist self bases historically turn the subaltern selves into several others from where no absolute other [culturally imposed] escapes (“Three Women's" 253). The abjective dimension of bestowing the status-subaltern other on the individuals demonstrates the concealed mechanism of imperialism that does not accepts Other as self and it promulgates inequality, oppression, subjugation, and degradation. In this context, Bertha is being dehumanized and demoralized and executes the role of different Otherness, and her self-possession and personal happiness find no humanitarian aids to fight those hierarchies and stiff conventional morality in which she lives.

Although Jane was against the rigid Victorian values represented by Britain's "imperial mission" and patriarchal social order, she has become a part of that order when instead of knowing that, she finally accepts Rochester's final proposal. In the novel, it is seen that St John Rivers is rejected by Jane because of his patriarchal social order that limits her to subservient roles. Jane as a 'proto-feminist' heroine struggles successfully to achieve female self-determination in an otherwise patriarchal and oppressive world only because her quest is to find a partner worthy of her intelligence, her judgmental wit, and her determined self-hood - are who will learn to respect her integrity and determination whether the man is colonialist or not.

Like many other critics, in The Madwoman in the Attic, Gilbert and Gubar studied Jane Eyre just as "moral gothic" (338) and a "story of enclosure and escape" 
(339). They praised Jane's "anger" and "disguised rebelliousness" to show Jane's attempt to escape from "the imprisonment of her childhood towards an almost unthinkable goal of mature freedom are symptomatic of difficulties Everyone in a patriarchal society must meet and overcome: oppression (at Gateshead), starvation (at Lowood), madness (at Thornfield) and coldness (at Marsh End)." (339)

They saw Bertha Mason as "the demon of rage" and in relation to Jane, never as an individual self in her own right, and Thornfield as "gothic trapping" (347). They never explored the causes of Bertha's lunacy and her representation and subalternity in terms of race and class. Their emphasis was that Bertha is "Jane's dark double," and "Bertha not only acts for Jane, she also acts like Jane" (361). Bertha's lunacy does not represent Jane's anger that she represses to be deemed an acceptable woman in a patriarchal world because it leaves out Bertha's creole identity and her imprisonment in Thornfield Hall and because it fails to examine the true nature of Bertha's lunacy and her representation. Herein lies the privileged position of liberal feminism that is pretentious and a type of 'neo orientalism that the "axioms of imperialism are said to repeat themselves in every feminist endeavor to essentialize or prescriptively name the alterity /difference of native female Others" (Gandhi 88-89). And such liberal academic feminism is thought of silencing and categorizing the native woman in its isolation and essentialization within literature while celebrating the emerging feminist ideals in European and AngloAmerican feminist tradition. Even Jane is not free from her derogative representation of Bertha as we notice when Rochester takes Jane to see Bertha just after the wedding disrupted by Mr. Mason, Bertha's brother.

In Jane Eyre, Bertha is robbed of human selfhood; she has no voice other than demonic laughter and the discomforting noises that Jane reports. Her animalistic character disqualifies her from the journey of human self-determination for which Jane is praised by Rochester. Bertha has been a victim of oppression and racial prejudice from colonialist discourse and the discourse of her own culture. Loomba's study emphasizes that certain class distinction is the result of the ideological formation of that particular race (109). After she comes to Rochester's estate at Thornfield Hall, Jane settles into the house and makes good relationships with many of the staff, but is occasionally disturbed at night by mysterious incidents. She is forced to pull a sleeping Rochester from his chamber which inexplicably has been set on fire. Even during the night before the wedding, Jane wakes to see reflected in her mirror a strange "dark figure" ripping her wedding veil in two. The next day, their wedding is interrupted by John Mason who claims that Rochester has already had a wife. Rochester is forced to admit that he is indeed married to Bertha Mason whom Rochester has kept locked up in the room above Jane. In the novel, it is noticed that the problematic representational systems violently displace and silence Bertha, the gendered subaltern. She is being degraded within the structures of epistemic violence of discourse and retains the disparate position of becoming a subaltern. Bertha is lost in dualism and "disappears, not into a pristine nothingness, but a violent shuttling which is the displaced figuration of the "third-world woman" caught between tradition and modernisation" (Spivak "Can the Subaltern" 280). 
The ideas behind the displacement and exclusion of the subaltern people from the privileged positions of their society are historically produced and represented by the hegemonic power relations in the framework of Eurocentric approach to history and political economy that legitimize the domination and presence of the colonizer in the non-European territories. In the same framework, Bertha is being denied her voice and suppressed-no ways are preordained for her self-expression, self-consciousness, and emancipation, and Rochester conducts the work of Eurocentric values in the exercises of colonial expansion, imperial policy, market economy, capitalist systems, patriarchal ideology, enlightenment, and universal approaches to that pave the ways of modernization in the developing countries. Whatever he does for the subordinated countries in the guise of the imperialist and colonialist missions, he denies the presence and voice of the subalterns.

In the novel, Bronte indirectly depicts the social, cultural, political and economic impacts of colonialization on the British privileged classes whose fortunes depend on these colonial rules. Rochester's fortune relies on plantations in Jamaica which he inherits through his marriage to Bertha, the daughter of a planter and merchant living in Jamaica. Bertha, a 'mad woman in the attic,' is made captive in England after she arrives from Jamaica, symbolizing 'Oriental Other.' Rochester's account of his marriage is nothing but a trick. He tells Jane that he is brought by Bertha's family for thirty thousand pounds because of his race and higher position in society. To Jane, he speaks of Bertha's "vile discoveries," "treachery of concealment," alien nature, "low, narrow" mind, and "intemperate and unchaste" wifehood (Bronte 270). Rochester frequently uses many adjectival derogative words and concepts such as "obnoxious," "incapable," "dark," "hell," "wild animal," "virile," “corpulent," "strange," "madness," “mixed race," "lunatic," "drunken," "magic," and "phantom," to refer to her nature while denying her status, background, and cultural heritage.

Rochester's derogatory use of dominant language dehumanizes Bertha and typically associates her with low creatures, unfriendly alien beings, and inferior race. To him, Bertha is a desirable commodity for both her money and her accomplishments. Rochester always doubts his emotional attachments and defines Bertha as an object, not a beloved wife. As Loomba remarks that colonizer's dominant language is "implicated in constructing the binary of a European self and a non-European Other, which [...] is a part of the creation of colonial authority" (66). His marriage to Bertha gains him a fortune of thirty thousand pounds and Jane inherits the fortune of twenty thousand pounds from her uncle John Eyre, a wine merchant from Madeira. Their fortunes and happiness are based on the colonial source of income. Even St John Rivers is connected with British missionary work in India only to consolidate the British colonial power. More significantly, this shows the dominant effects of the processes of colonialism, racism, and imperialism. Edward Said precisely holds the effective and exclusive nature of them that are basically "impressive ideological formations" and "affiliated with dominations" [..] words and concepts like "inferior," or "subject races," "subordinate people," "dependency," "expansion," and "authority" (Culture 9). What his study implies 
is the hegemonic ideological discourse of the West and its justification for the exploitation and domination of the non-Western Other. With the establishment of colonial rule, such a discourse of difference and domination excludes the space of the oppressed peoples who are the constant receivers of the diverse forms of discrimination. In this context, Rochester's abusive use of language and domination over Bertha in diverse forms proves the Eurocentric method of retaining power structures and authority in the existing discursive practices.

Jane is seen as a version of the emblematic English lady, the symbol of English values, and the queen of England. She is unwilling to be identified as a colonized 'Other.' She challenges the colonialist assumptions by which European colonizers express their desires to be masters of the native people in the name of modernity and civilization, also seen in the character of Prospero who seizes the land from Caliban, Sycorax, and Ariel, the real inhabitants. However, it is intelligible that both Jane and Rochester lead a happy life based on the edge of colonialism and imperialism. The Western projection of making the subaltern identity of the Third World people through its dominant discursive practices is found in the dehumanizing description of Bertha by Jane. She depicts Bertha as a "figure"-not sure whether it is "beast or human being" (Bronte 258).

The revelation of Bertha solves the mystery at Thornfield Hall by allowing Jane to look upon that hidden face that has been hitherto concealed by Rochester. The presence of Bertha problematizes Jane's imprecise description and her omniscient narration by showing its limits to the extent of Bertha's silence who threatens to escape that which confines and silences her. Rochester's ironical account of his marriage shows a "fiery West Indian night" (Bronte 272) during which he contemplated suicide rather than having to endure the future with his "lunatic" wife. He says that he was "unable to sleep in bed," and he "was physically influenced by the atmosphere and scene" (Bronte 271-272). Moreover, Rochester constructs the demonic impression of Jamaica as hell-on earth and how this demonic atmosphere has affected Bertha, who similarly displays fiery, tempestuous, lunatic and turbulent behavior. What saves him from Bertha's madness and Jamaica's hellish atmosphere is "a wind fresh from Europe" (Bronte 272).

Rochester's words reveal the unquestioned ideology of colonialist structure based on 'Manichaean' oppositions: "sweet wind from Europe" as opposed to "the fiery West Indian night" (Bronte 272). Although all depictions about Bertha and Creole people in Jane Eyre come from Rochester's long narration, Rhys's Wide Sargasso Sea highly displays Bronte's "unthinking prejudices."

Rhys's Wide Sargasso Sea places Bertha center-stage, allowing her the possibility to achieve self-hood and granting her the opportunity to present her point of view. The novel discloses that subaltern figure like Bertha can articulate her feelings, desires, and rights, not because of her inherent inability or lack of individual identity and consciousness, but because of the distortions of power structure and discourse. Carine Mardorossian writes that Rhys's novel represents a recognition of the resistance of the protagonist by protesting against the typical stereotypes of colonialism and imperialism 
that renders her into a madwoman and an objective- passive-receiver of multiple oppressions (1078).

The plot is a reevaluation of the subaltern character from Jane Eyre. In Wide Sargasso Sea, she is renamed Antoinette Cosway and discloses her revolutionary spirits to be free from the slavery of her husband, her own family, her host society, and her home society - an individual with full aspirations for freedom, love and equality. Having set in Jamaica, the novel not only gives expression to Bertha to articulate her views, to resist supremacy of dominant discourses of colonization and racialization, but also shows the disguised nature of Rochester especially his patriarchal and colonialist ideology reflected in his engagement in plantations and exploitations of native peoples in Jamaica. As a Jamaican white Creole, Antoinette grows up in a racial situation and she encounters verbal abuse, such as "white cockroach," [...] Nobody want you. Go away" by the English people and "white nigger" by the black peoples not knowing where to belong to (Rhys 20). She is, however, neither Afro-Caribbean nor 'beke' [white person], so she seems to be hated by both home and host society. Rochester is driven by Antionette's wealth and at the same time repulsed by her racial otherness. Just before Antoinette recounts her mother's story, Rochester's thought of the feelings of something unknown and unfriendly was very strong. Rochester endeavours to efface this otherness by renaming her Bertha. The act of renaming a woman by a man or her husband in a derogative way brings forth the notion of the dehumanizing legacy of colonization. Antoinette objects to this imposed image on herself.

Not only does Rochester confers her with another name, disregarding her as an individual identity, but he treats Antoinette like an object. He mistreats her and finally locks her up in a house after learning about the illness of her mother. He repents that he is bound to a lunatic wife who resembles her mother-a lunatic. Antoinette regrets what she left in the West Indies and lacks in England. Rochester marries and loves Antoinette only for money or perhaps for lust and power. In the novel, Antoinette's representation of events comes into competition with her husband's. The exotic backdrop is embodied in Antoinette as a 'zombi,' "the spirit of a place" addressed by her husband (Rhys 97). Her survival is for the survival of the Caribbean against European patriarchy and imperialism. Her struggle is for having a voice to reinscribe a past Caribbean history and construct her own indigenous cultural identity not to be dependent on the foreign or white culture. Therefore, in this way the novel answers back and critically examine the views of Caribbean people and places that are lowered or reduced in Jane Eyre.

Rochester lacks knowledge of local customs and is skeptical of Jamaica. He is uncomfortable with the island and its inhabitants, especially Christophine and Sandi Cosway. He complains about Christophine's language and dress. Furthermore, he is very blind enough to believe Daniel Cosway, Antoinette/Bertha's half-brother who tells him about the madness of the Cosway family. Rochester has a sexual encounter with a black servant, Amelie, a purely racial Other, instead of with forbidden Antoinette. Christophine, the black servant from Martinique is a more troubling figure for Rochester as she is outspoken, assertive, and independent. Antionette persuades Christophine to use 
the power of her 'obeah' to make Rochester love her. Throughout the novel we find that Antoinette goes through the experiences of childhood threat, racial and gender discrimination, isolation, alienation, oppression, colonized otherness, arranged marriages, wife-husband relationships, displacement, exile, and identity crisis. As a Creole, however, Antoinette is born of "mixed race," neither Afro-Caribbean nor white person, so not knowing where to she belongs. When their relationship gets worst, Rochester takes an even harsher attitude towards her. He depicts her as "the pale silent creature" and his marriage and happiness were a mere pretension for her to rob her property. To him Antionette's true feelings were nothing but like a stranger "who did not think or feel as I [he] did" (Rhys 85). Antoinette's voice differs from her husband's dominant and racial prejudice that fail to make true love and bond between them when she asserts:

" No. And what do I care if he does? He hates me now. I hear him every night walking up and down the veranda [. . .] Going away to Martinique or England or anywhere else, that is the lie. He would never give me my money to go away and he would be furious if I asked him. There would be scandal if I left him and he hates scandal. Even I got away (and how?) he would force me back. So would Richard. So would everybody else." (Rhys 102-03)

In the above passage it is explicit that Bertha is torn between outside and inside, a victim of her husband and her society-doubly colonized and marginalized by those imposed double standards. In her dream-England, she finds an environment of binaries and hierarchies in comparison to her Caribbean life. While reading the novel, some questions arise: Is Bertha or Antoinette really mad or driven to behave like a mad? From both texts the answer is explicit in the sense that her fall into madness is a psychic response to those inhuman rigid laws and social constructions which degrade her individual freedom and choice- her position is in in-between of society, not complete but tormented - 'white cockroach' and 'black nigger.' Her mother led a similar life and experienced similar dehumanizing behaviors. Rochester marries her only to gain her wealth and when the marriage is over, he shows himself as a representative of European values that are much higher and rational than Antoinette's racial otherness. He locks her in the Thornfield Hall because he could not accept her Otherness, always doubtful of his emotional attachment and he felt strange in the Jamaican environment, and finally, this act drives Bertha/Antoinette into real madness. It is rather a response to a profound sense of isolation, exile, alienation, cultural displacement, marginalization, and oppression caused by Rochester. After she arrives in England, she suffers the loss of her individual self and highly resembles the Afro-Caribbean 'zombie.' Spivak insists on the complicit nature of representational systems, subjectivity, and meaning that "although the history of Europe as Subject is narrativized by the law, political economy, and ideology of the West, this concealed Subject pretends it has no "geopolitical determinations"" (Can the Subaltern" 238). Rochester, under the guise of a false relationship with Bertha, as a dominant Subject performs this act to fulfill his desire, to seize the property of Bertha, to 
conquer the West Indies, to dominate its native people and to fix value systems on them based on a profound conflict in all spheres of their lives.

In the final section of her dream, Antionette devises a plan of setting fire to the house and a firm resolution to all those problems that she endures. After waking she takes up her candles and keys from the slumbering Grace Pole and sets fire to Thornfield Hall. She resolves "what I have to do" and dies in the fire (Rhys 171). However, all kinds of inhumanity and injustice were done to Antoinette/Bertha suggest that the identity or union with the native Other finds a place in a purgative fire that transforms all kinds of painful ambivalence and dehumanized objects into a joyful unity of difference. In the novel, the symbol of "fire" is only highly related to the sense of "justice" for the subalterns.

In Jane Eyre, Bertha is seen as a violent soul and a prototype of madwoman and given no voice to her at all, and all the more stereotypical accounts are provided by Rochester and Jane. She is placed in a dark room, hidden from the world, seen as a "wild animal," invisible, voiceless "ghost," unable to talk or understand others; the only means of language is for her is laughter. Unlike Bronte's, Rhys gives her a voice and her identity as a Creole girl, she lives between two worlds; her struggle is much harder because of her complex origin - a doubly oppressed. Rochester always attempts to dominate her and shows his racial superiority-a kind of parallel-white/black, master/slave, colonizer/colonized, dominant/dominated, light/dark-an imposed assumption that associates Creole people with all negative aspects of the human. Moreover, she is never free from those imposed stereotypes and oppression and repression: but a double victim of her society and her adapted one; she fails all the time to find a place in her way of living or to be accepted by others.

Being treated as the subaltern, Bertha/Antoinette's inferiority and madness are caused by people who impose their ideologies and hegemonic cultural assumptions on the marginalized. She is hated and oppressed by others to the extent that no other ways were open to her to take revenge from their oppressors and to assert her identity other than by destroying Thornfield Hall. It is her only response to break up the "narrow epistemic violence of imperialism" (Spivak "Can the Subaltern" 257). The "epistemic violence' of the Western assumptions on the subaltern makes individual subjects into the 'universal metaphysical difference' to place the subaltern a negative image and to retain the shadow of the colonizer's self-image. She is always forced to 'abject' her own identity and subjectivity, torn into pieces by everyone around her. Her identity is 'interpellated' through the paradoxes of the functioning of the 'hegemonic ideologies' and 'discourses' of the West and is acknowledged in its stereotypical representation, but not in its fullest humanistic approach.

\section{Conclusion}

The article aimed to study the major mechanisms of colonialist and imperialist discourses and their ideological roles in the processes of subalternity. The textual analysis implicates that the conception of subalternity is historically situated through the 
male-dominated discourses to signify the 'Manichaean dualism.' In both texts, Bertha Mason, the epitome of the subaltern identity, darkness, savage, madness, and evil is the victim of both Victorian colonialist ideology which devalues her and Jamaica because of her race and cultural ancestry, and patriarchal ideology which devalues her society because of her sex. She is the victim of double oppression not only at the hands of colonialists but within her own patriarchal cultures as well.

The recovery of the autonomy of the subaltern subject-Bertha/ Antoinette Cosway fails because subalternity is constituted by discursive structures of imperialism and patriarchy as much for what they exclude as for what they determine. The subaltern's resistance against the Western domination of power, discourse, subjectivity, and representation fails because the subaltern's search for a humanist subject-agent is broken or discursively authorized and institutionalized by the dominant groups. However, the position of the subaltern identity in the operation of the dominant discourses is always silenced and stereotyped resembling the 'history from below' approach devised by the Western ideology.

\section{Works Cited}

Bronte, Charlotte. Jane Eyre. Wordsworth Classics, 1999.

Buttigieg, Joseph A. "Subaltern Social Groups in Antonio Gramsci's Prison Notebooks." The Political Philosophies of Antonio Gramsci and B.R. Ambedkar: Itineraries of Dalits and Subalterns, edited by Cosimo Zene, Routledge, 2013, pp. 35-42.

Gandhi, Leela. Postcolonial Theory: A Critical Introduction. Allen and Unwin, 1998.

Gilbert, Sandra M., and Susan Gubar. The Madwoman in the Attic: The Woman Writer and the Nineteenth-Century Literary Imagination. $2^{\text {nd }}$ ed., Yale Nota Bene Yale UP, 2000.

JanMohamed, Abdul R. "The Economy of Manichean Allegory: The Function of Racial Difference in Colonialist Literature." Critical Inquiry, vol. 12, no. 1, Autumn 1985, pp. 59-87. JSTOR, www.jstor.org/stable/1343462.

Loomba, Ania. Colonialism/Postcolonialism. $2^{\text {nd }}$ ed., Routledge, 2005.

Maggio, J. "Can the Subaltern be Heard? Political Theory, Translation, Representation, and Gayatri Chakravorty Spivak.” Alternatives, vol. 32, 2007, pp. 419-43.

Mardorossian, Carine M. "Shutting up the Subaltern: Silences, Stereotypes, and DoubleEntendre in Jean Rhys's "Wide Sargasso Sea." Callaloo, vol. 22, no. 4, Autumn 1999, pp. 1071-90. JSTOR, www.jstor.org/stable/3299872.

Prakash, Gyan. "Subaltern Studies as Postcolonial Criticism." The American Historical Review, vol. 99, no. 5, 1994, pp. 1475-90. JSTOR, www.jstor.org/stable/2168385.

Rhys, Jean. Wide Sargasso Sea. Introduction by Francis Wyndham. W.W. Norton, 1982.

Said, Edward W. Culture and Imperialism. Vintage Books, 1994.

---. Orientalism. Penguin Classics, 2003. 
Spivak, Gayatri Chakravorty. "Can the Subaltern Speak?" Can the Subaltern Speak? Reflections on the History of An Idea, edited by Rosalind C. Morris, Columbia UP, 2010, pp. 237-92. (Reprinted from Marxism and Interpretation of Culture, edited by Cary Nelson and Lawrence Grossberg, Macmillan, 1998, pp. 271-313.

---. “Three Women's Texts and a Critique of Imperialism.” Critical Inquiry, vol. 12, no. 1, Autumn 1985, pp. 243-61. JSTOR, www.jstor.org/stable/1343469.

\section{The Authors}

\section{Sahabuddin Ahamed}

Ph.D. Research Scholar,

Department of English and Foreign Languages,

Guru Ghasidas Vishwavidyalaya (Central University), Bilaspur, India.

Email-ahamedggu@gmail.com

\section{The Article}

Date sent: 24/08/2021

Date revised: 18/10/2021

Date Accepted: 18/10/2021 